\title{
CHEMICAL AND FUEL PROPERTIES OF FORESTRY WASTES FROM PINE PLANTATIONS ${ }^{1}$
}

Rafael de Avila Delucis ${ }^{2 *}$, Patricia Soares Bilhalva dos Santos ${ }^{3}$, Rafael Beltrame ${ }^{4}$ and Darci Alberto Gatto ${ }^{4}$

\footnotetext{
${ }^{1}$ Received on 28.07.2015 accepted for publication on 24.08.2017.

${ }^{2}$ Universidade Federal do Rio Grande do Sul, Programa de Pós-Graduação em Engenharia de Minas, Metalúrgica e de Materiais, Porto Alegre, RS - Brasil. E-mail: <r.delucis@hotmail.com>.

${ }^{3}$ Universidade Federal do Pará, Faculdade de Engenharia Florestal, Altamira, PA - Brasil. E-mail: <patricia.bilhalva@hotmail.com>.

${ }^{4}$ Universidade Federal de Pelotas, Programa de Pós-Graduação em Ciência e Engenharia de Materiais, Pelotas, Rio Grande do Sul - Brasil.E-mail:<beltrame.rafael@yahoo.com.br> and <darcigatto@yahoo.com.br>.

*Corresponding author.
}

\begin{abstract}
Power plants have been using forestry biomasses to produce thermal and electrical energies. However, these industries lack of reliable parameters about their raw material in order to consolidate their position in this market. The present study aimed to characterize forestry wastes from pine (Pinus elliottii) plantations leftover of wood logs processing units. Wood, bark and a mixture of both of them were characterized by prompt (total moisture, hygroscopic moisture, ashes, volatile matter and fixed carbon contents), elementary ( $\mathrm{S}, \mathrm{C}, \mathrm{H}, \mathrm{N}$ and $[\mathrm{O}+\mathrm{Halogens}]$ contents), and via wet (holocellulose, lignin and extractives contents) chemical analyses. Indeed, basic density and fuel properties (gross and net calorific values) were also determined. Compared to the wood, the bark presented higher extractives content, which affected the ashes content. Regarding the energetic properties, the bark showed the highest properties, but a detrimental character from an environmental standpoint. The wood-bark mixture presented intermediate properties between these two forestry wastes, but with more approximation to the wood.
\end{abstract}

Keywords: Wood bark; Pinus elliottii; Calorific value.

\section{PROPRIEDADES QUIMMICAS E ENERGÉTICAS DE RESÍDUOS FLORESTAIS PROVENIENTES DE PLANTAÇÕES DE PINUS}

\begin{abstract}
RESUMO - Usinas vêm utilizando biomassas de base florestal para a produção de energia térmica e elétrica. Nada obstante, essas industriais carecem de parâmetros confiáveis sobre sua matéria prima, a fim de consolidar sua posição nesse mercado. O presente estudo objetivou caracterizar resíduos florestais provenientes de plantações de pinus (Pinus elliottii) sobressalentes de serrarias. A madeira, a casca e uma mistura de ambas foram caracterizadas por análises químicas imediata (Teores de umidade total, umidade de higroscopia, cinzas, matérias voláteis e carbono fixo), elementar (Teores de $S$, $\mathrm{C}, \mathrm{H}$, Ni e [O + Halogênios]), via úmida (Teores de holocelulose, lignina e extrativos). Adicionalmente, densidade e propriedades energéticas (poderes caloríficos superior e inferior) também foram determinados. A casca apresentou maior teor de extrativos comparada a madeira, o que afetou o teor de cinzas. Em relação as propriedades energéticas, a casca apresentou as maiores propriedades, embora também um caráter depreciativo do ponto de ambiental. A mistura madeiracasca apresentou propriedades intermediárias entre esses dois resíduos, embora mais aproximadas às da madeira.
\end{abstract}

Palavras-Chave: Casca; Pinus elliottii; Poder calorífico. 


\section{INTRODUCTION}

Forestry biomasses are currently from two sources in Brazil, namely energetic forests and forestry wastes. However, there are few forests exclusively addressed to produce energy, and hence, the industrial sector often prioritizes the use of forestry wastes. Most of these wastes are from debarked wood logs, and because of that, the bark remains underutilized for power production (Miranda et al., 2012).

For decades, and even nowadays, solid fuels from forests have been playing an important role in the Brazilian energy matrix, since there is a huge availability of forests in this country (Agência Nacional de Energia Elétrica, 2014). According to data recorded by Agência Nacional de Energia Elétrica (Agência Nacional de Energia Elétrica, 2014), 53 thermoelectric plants are in operation in Brazil using wastes leftover of wood logs processing, which are responsible for about $0.3 \%$ of all installed generating capacity (i.e. $438 \mathrm{~kW}$ ).

Regarding the international scenario, the market of forest-based fuels is dominated by Canada and United States, and represents about 1.6 billions of R\$ (i.e. almost 0.5 billion US\$) with growth expectation (Food and Agriculture Organization Corporate Statistical Database, 2014). According to Associação Brasileira de Celulose e Papel (Associação Brasileira de Celulose e Papel, 2014), among the main forest species, there are 1.6 million ha of pine forests planted in Brazil for industrial proposes, comprising up to hundreds of species, but Pinus elliotti stands out due to its good physicomechanical properties, fast growth, pest resistance, and valuable resin.

The biomass sector is dependent of several efforts, including: encouraging fiscal policies, increasing planted forests, setting of sustainable forest management procedures, creating a favorable business atmosphere, supporting process improvements, and so on. Nevertheless, all these points depend of reliable technical parameters capable of define the potential of the raw material used to produce clean energy, which are not yet been elucidated for wood and bark. In this sense, knowing chemical features is imperative, since they influence in fuel properties.

In this sense, gross and net calorific values are the main fuel properties (Günther et al., 2012; Komilis et al., 2012). On the other hand, carbon, oxygen and hydrogen contents are important properties in any elementary chemical analysis (Villanueva et al., 2011; Komilis et al., 2012). Besides, density and moisture content are commonly evaluated in studies focused on energetic features, since they are physical parameters controlled in the processing of biomasses (Krajnc, 2015). Nevertheless, via wet chemical analyses are also mostly applied for wood and other lignocellulosic materials, in order to obtain extractives, lignin, cellulose and hemicellulose contents (Fang et al., 2013; Chen et al., 2014).

In this context, these chemical properties are dependent of certain factors, such as material age, growth rate, as well as both axial and radial positions (Shanavas and Kumar, 2003; Lemenih and Bekele, 2004). On the other hand, energetic features are dependent of some chemical properties, especially amount of aromatic compounds, which are mostly present in lignin, and even in extractives (Kataki and Konwer, 2001; Günther et al., 2012). Thereby, both chemical and energetic properties vary even in a comparison between trees from clonal seedlings (Fang et al., 2013; Turinawe et al., 2014). Based on the described scenario, the present study aimed to investigate forestry wastes from pine commercial plantations in order to estimate their energetic potential by means of chemical and energetic properties.

\section{MATERIALS AND METHODS}

\subsection{Raw material selection and preparation}

Wood (I), wood-bark mixture (II), and bark (III) (shown in Figure 1) were selected in a thermoelectric plant located in Piratini, southern Brazil. These materials are leftover of wood-logs processing units located near the plant. The sample "I" consisted in wood flakes free of impurities, and the sample "II" presented a 60$70 \%$ wood content, as normally used in the thermoelectric plant.

\subsection{Chemical composition determined by immediate analysis}

Total and hygroscopic moistures contents were determined in accordance with ASTM D7582, (American Society for Testing and Materials, 2012). Following the same standard procedure, ashes, volatile matter, and fixed carbon contents were defined by macro thermal gravimetric analysis in a thermal gravimetric analyzer TGA 701 (LECO Corporation).

Revista Árvore. 2017;41(5):e410507 


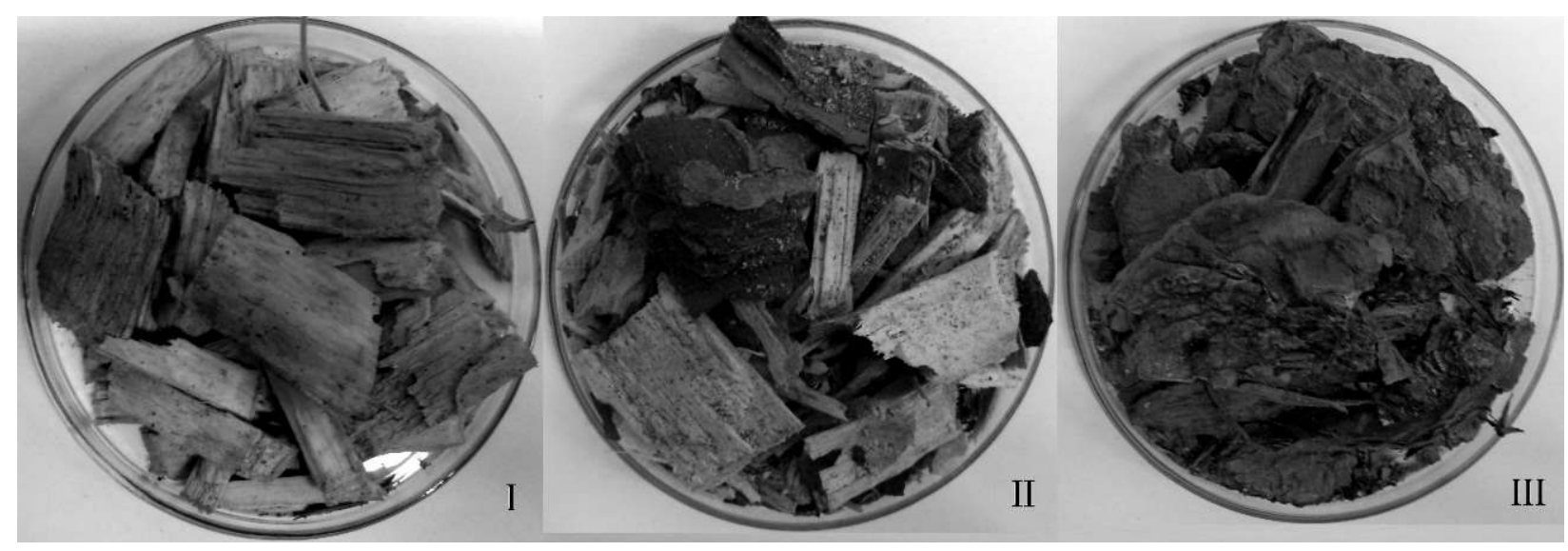

Figure 1 - Forestry wastes from pine plantations. Where I, II, and III are wood, wood-bark mixture, and bark, respectively. Figura 1 -Resíduos florestais provenientes de plantanções de pinus. Onde: I, II e III são madeira, mistura madeira-casca, e casca, respectivamente.

\subsection{Chemical composition determined by elementary analysis}

Total sulfur content (sample combustion with detection by infrared) was determined in a TruSpec Sequipment(LECO Corporation) following ASTM D4239, (American Society for Testing and Materials, 2014b). Carbon, hydrogen and nitrogen (sample combustion with detection by infrared and thermal conductivity) contents were determined in a TruSpec $\mathrm{CNH}$ equipment (LECO Corporation). Indeed, [oxygen + halogens] content was determined in accordance with ASTM D3176, (American Society for Testing and Materials, 2009).

\subsection{Basic density and energetic propertiesh}

Gross and net calorific values were determined in a calorimetric isoperibolic pump according to ASTM D5865, (American Society for Testing and Materials, 2013). The gross calorific value was directly obtained, and the net calorific value was calculated through equation provided by the standard procedure. According to this standard procedure, the net calorific value corresponds to the amount of heat released during the combustion of a substance at $0.1 \mathrm{MPa}$ constant pressure with any water remaining in form of vapor. Basic density was determined in an analytical balance ( $0.01 \mathrm{~g}$ resolution) following water immersion method described in ASTM D2395, (American Society for Testing and Materials, 2014a).

\subsection{Chemical characterization via wet}

Finally, the forestry wastes were prepared (Tappi $257 \mathrm{~cm}-02$; Technical Association of the Pulp and Paper Industry, 2002) and characterized to obtain extractives (T204 om-97; Technical Association of the Pulp and Paper Industry, 1997), holocellulose (WISE et al. 1946), and acid-insoluble lignin (T222 om-98; Technical Association of the Pulp and Paper Industry, 1998) contents.

\section{RESULTS}

Regarding the elementary chemical composition shown in Table 1, the bark presented the highest nitrogen content, with differences of $127 \%$ and $100 \%$ compared to the wood and the wood-bark mixture, respectively.

All forestry wastes presented similar carbon, hydrogen, and [oxygen + halogens] contents (data shown in Table 1). According to the wet chemical results,

Table 1 - Elementary chemical composition of the forestry wastes.

Tabela 1-Composição química elementar dos resíduos florestais.

\begin{tabular}{lccc}
\hline & Wood & $\begin{array}{c}\text { Wood-bark } \\
\text { mixture }\end{array}$ & Bark \\
\hline Total sulfur & 0.01 & 0.01 & 0.03 \\
Carbon & 53.17 & 53.07 & 56.27 \\
Hydrogen & 6.00 & 5.93 & 5.46 \\
Nitrogen & 0.11 & 0.14 & 0.25 \\
[Oxygen + Halogens] & 40.17 & 40.6 & 36.93 \\
\hline
\end{tabular}

Revista Árvore. 2017;41(5):e410507 
the bark presented the highest extractives content, the highest acid-insoluble lignin content, and the lowest holocellulose content (Table 2).

As stated for the wastes composition determined by elementary analyses, the wood and the wood-bark mixture presented similar properties obtained by immediate analyses (Table 3), which is due to the higher amount of wood than of bark in the mixture of both of them. The bark presented both the lowest total moisture and the lowest volatile matter contents. Indeed, the bark presented the highest fixed carbon with differences of $64.77 \%$ and $60.73 \%$ compared to the wood and the wood-bark mixture, respectively.

The moisture content (Table 3 ) influenced both the gross and the net calorific values (Table 4) due to the amount of energy required to vaporize the remaining moisture in the forestry wastes. As shown in Table 4, the bark presented higher gross and net calorific values than both the wood $(4.38 \%$ and $4.82 \%$,

Table 2 - Chemical composition of the forestry wastes determined via wet analysis.

Tabela 2 - Composição química dos resíduos florestais determinada por análise via-úmida.

\begin{tabular}{lccc}
\hline & Wood & $\begin{array}{c}\text { Wood-bark } \\
\text { mixture }\end{array}$ & Bark \\
\hline Holocellulose (\%) & 55.21 & 57.05 & 36.74 \\
Lignin (\%) & 31.21 & 33.43 & 36.78 \\
Extractives (\%) & 2.45 & 3.06 & 3.83 \\
\hline
\end{tabular}

Table 3 - Chemical composition of the forestry wastes determined by prompt analysis.

Tabela 3 - Composição química dos resíduos florestais determinada por análise imediata.

\begin{tabular}{|c|c|c|c|}
\hline & Wood & $\begin{array}{l}\text { Wood-bark } \\
\text { mixture }\end{array}$ & Bark \\
\hline Total moisture (\%) & 52.29 & 52.83 & 40.67 \\
\hline opic moisture $(\%)$ & 2.94 & 2.65 & 5.95 \\
\hline Ashes $(\%)$ & 0.54 & 0.25 & 1.06 \\
\hline Volatile matter (\%) & 81.97 & 81.82 & 70.12 \\
\hline Fixed carbon $(\%)$ & 17.49 & 17.93 & 28.82 \\
\hline
\end{tabular}

Table 4 - Basic density, gross and net calorific values of the forestry wastes.

Tabela 4-Massa especifica, e poderes calorificos superior e inferior dos residuos florestais.

\begin{tabular}{lccc}
\hline \multicolumn{3}{c}{ Wood } & $\begin{array}{c}\text { Wood-bark } \\
\text { mixture }\end{array}$ \\
\hline Basic density $\left(\mathrm{kg} . \mathrm{m}^{-3}\right)$ & 393 & 388 & 372 \\
Gross calorific value $\left(\mathrm{J} . \mathrm{g}^{-1}\right)$ & 20,515 & 20,430 & 21,415 \\
Net calorific value $\left(\mathrm{J} . \mathrm{g}^{-1}\right)$ & 19,215 & 19,155 & 20,245 \\
\hline
\end{tabular}

Revista Árvore. 2017;41(5):e410507 respectively) and the wood-bark mixture (5.36\% and $4.78 \%$, respectively).

\section{DISCUSSION}

The higher hydrogen content obtained for the bark compared to the wood is an undesired feature from an environmental standpoint, and because of that, the bark may generates toxic substances when incinerated (Johnsson, 1994).

Regarding the total moisture content, the bark retained low levels of water between its anatomical elements, which is due to its low amount of intercellular roles (Evert, 2006). Moreover, these two forestry wastes might underwent a diverse influence related to their drying occurred throughout both their generation and their sampling (Brand et al., 2010; Silvério et al., 2011).

According to Vale et al., (2000), a moisture content lower than $25 \%$ is recommended to produce thermal energy according to a satisfactory cost-benefice relationship. Hence, biomasses used in thermoelectric plants have to receive special attention related to their moisture content, and this way, this raw material should be dried prior to its pyrolysis.

Regarding the volatile matter content, the wood probably presents a higher flammability than the bark, since in a general way, the higher the volatile matter content, the higher the flame spreading, and the lower the ignition time (Yaman, 2004). This also explains the fixed carbon content, which was highest for the bark. Previous studies reported an important role played by their fixed carbon content on calorific value of solid fuels (Komilis et al., 2012; Pirraglia et al., 2012).

In general, volatile compounds quickly become combustion gases when lignocellulosic materials (c.a. wood and bark) are under pyrolysis, and on the other hand, carbonated compounds (represented by the fixed carbon content) present a slow thermodegradation. The latter case can be exemplified by lignin, which decomposes along a $100-900{ }^{\circ} \mathrm{C}$ temperature range (Yang et al., 2007) within partly becomes fixed carbon (Missio et al., 2014).

The bark presented the highest hygroscopic moisture content, the highest ashes content and the highest fixed carbon content. Once ashes are leftover of the combustion, and they may affect both calorific value and heat transfer in a negative way (Kataki and Konwer, 2001), the results obtained for ashes content favor the use of the wood or the wood-bark mixture against 


\section{Chemical and fuel properties of forestry...}

the bark. The ashes content for the bark case can be attributed its nutrients present due to the intense physiological activity of this vegetal tissue, although impurities can also be adhered on it due to the logs processing (Olanders and Steenari, 1995).

High ashes contents in solid fuels can lead to the formation of corrosion and incrustations in boilers and furnaces, which may decrease their shelf life (Kjällstrand and Olsson, 2002). Because of that, this type of equipment should be rigorously designed to avoid both shelf life decreases and environmental damages due to toxic wastes, such as non-methane hydrocarbons and methyl chloride (Czapiewski et al., 2002). According to Mattos et al. (2016), gases from the pyrolysis of extractives from a pine (Pinus taeda) from southern Brazil (as the studied raw material) present toxic compounds, such as styrene, vanillin, D-limonene, and oleic acid. Therefore, both combustion gases and ashes generated along the pyrolysis of lignocellulosic materials are toxic wastes.

All forestry wastes presented similar averages in basic density, which indicates that there was no relation between this parameter and energetic properties. Nevertheless, the density of forestry wastes is strategically important due to costs related to their transport. With basis on Table 2, the bark presented the lowest holocellulose content, the lowest lignin content, and the highest extractives content. These chemical properties can explain the highest energetic properties of the bark, since lignin and extractives present high levels of aromatic compounds (Kataki and Konwer, 2001; Demirbas, 2002; Fang et al., 2013).

All chemical properties determined by elementary, immediate and via wet analyses are in agreement with results already published in literature, which is also a fact about basic density and energetic properties. For Chen et al. (2014), who evaluated pinewoods from North America, extractives and lignin contents were $4.6 \%$ and $28.8 \%$, respectively. Mattos et al. (2016), who evaluated a pinewood (Pinus taeda) from Rio Grande do Sul state, determined 6\%, 31\%, 51\%, and $0.4 \%$ for extractives, lignin, holocellulose, and ashes contents, respectively. Regarding the elementary chemical properties, Villanueva et al. (2011) analyzed a pinewood from a Spanish forest, and obtained 52\%, $6 \%, 1.5 \%$, and $39 \%$ for $\mathrm{C}, \mathrm{H}, \mathrm{N}$, and $\mathrm{O}$ contents, respectively.
Regarding the total sum of compounds determined via wet, the properties obtained in the present study are inside the $79-95 \%$ range reported in literature by Garcia et al. (2014) and Santos et al. (2014), who evaluated several lignocellulosic materials, such as woods, barks, stalks, and etc. Therefore, the whole results suggested that to apply classification plans in order to separate each forestry waste leftover of processing wood logs units can affects in a positive way their performance as solid fuels, leading to enhanced thermal energy yields.

\section{CONCLUSION}

Regarding the chemical properties, the bark and the wood were different of each other due to the extractives content, which reflected in their ashes content. In relation to the energetic properties, the bark presented higher properties than the wood, although an adverse environmental character, since it may generates toxic wastes (combustion gases and ashes). The wood-bark mixture presented intermediate properties, but more proximate to the wood. All forestry wastes presented moisture contents up to that recommended in literature for biomasses. To determine the wood-bark proportion is recommended for a reliable use of any mixture of these two resources, in order to reach increased thermal energy yields and avoid shelf life decreases in boilers and furnaces.

\section{REFERENCES}

Agência Nacional de Energia Elétrica. Banco de informações de geração [Internet]. Distrito Federal: ANEEL; 2014 [cited 2014 Dec 29]. Available from: http://www.aneel.gov.br/ aplicacoes/capacidadebrasil/ GeracaoTipoFase.asp?tipo $=2 \&$ fase $=3$

American Society for Testing And Materials. D3176: standard practice for ultimate analysis of coal and coke. West Conshohocken: ASTM; 2009.

American Society for Testing And Materials. D2395: standard test methods for density and specific gravity (relative density) of wood and wood-based materials. West Conshohocken: ASTM; 2014a.

American Society for Testing And Materials. D4239: standard test method for sulfur in the analysis sample of coal and coke using high- 
temperature tube furnace combustion. West Conshohocken: ASTM; 2014b.

American Society for Testing And Materials. D5865: standard test method for gross calorific value of coal and coke. West Conshohocken: ASTM; 2013.

American Society for Testing And Materials. D7582: standard test methods for proximate analysis of coal and coke by macro thermogravimetric analysis. West Conshohocken: ASTM; 2012.

Associação Brasileira de Celulose e Papel. A indústria brasileira de árvores (Ibá) [Internet]. São Paulo: BRACELPA; 2014 [cited 2014 Dec 29]. Available from: http://www.bracelpa.org.br/shared/ iba_2014_pt.pdf

Brand MA, Muñiz CIB, Quirino WF, Brito JC. Influence of storage time on the quality of biomass for energy production in humid subtropical regions. Cerne. 2010;16(4):531-7. http://dx.doi.org/10.1590/S0104-77602010000400012.

Chen Y, Tshabalala MA, Gao J, Stark NM, Fan Y, Ibach RE. Thermal behavior of extracted and delignified pine wood flour. Thermochim Acta. 2014;591(10):40-4. http://dx.doi.org/10.1016/ j.tca.2014.06.012.

Czapiewski KV, Czuba E, Huang L, Ernst D, Norman AL, Koppmann R, et al. Isotopic composition of non-methane hydrocarbons in emissions from biomass burning. J Atmos Chem. 2002;43(1):45-60. http://dx.doi.org/10.1023/ A:1016105030624.

Demirbas A. Relationships between heating value and lignin, moisture, ash and extractive contents of biomass fuels. Energy Exploration \& Exploitation. 2002;20(1):105-11. http://dx.doi.org/ 10.1260/014459802760170420.

Evert RF. Esau's plant anatomy: meristems, cells, and tissues of the plant body: their structure, function, and development. 3nd ed. New Jersey: John Wiley \& Sons; 2006. http://dx.doi.org/ 10.1002/0470047380.

Fang S, Zhai X, Wan J, Tang L. Clonal variation in growth, chemistry and calorific value of new poplar hybrids at nursery stage. Biomass Bioenergy. 2013;54(7):303-11. http://dx.doi.org/ 10.1016/j.biombioe.2012.10.005.

Food and Agriculture Organization Corporate Statistical Database. Forestry production and trade [Internet]. Rome: FAOSTAT; 2014 [cited 2014 Dec 29]. Available from: http://faostat3.fao.org/ download/F/FO/E

Garcia A, Alriols MG, Labidi J. Evaluation of different lignocellulosic raw materials as potential alternative feedstocks in biorefinery processes. Ind Crops Prod. 2014;53(2):102-10. http:// dx.doi.org/10.1016/j.indcrop.2013.12.019.

Günther B, Gebauer K, Barkowski R, Rosenthal M, Bues CT. Calorific value of selected wood species and wood products. Eur J Wood Wood Prod. 2012;70(5):755-7. http://dx.doi.org/10.1007/s00107012-0613-z.

Johnsson JE. Formation and reduction of nitrogen oxides in fluidized-bed combustion. Fuel. 1994;73(9):1398-415. http://dx.doi.org/10.1016/00162361(94)90055-8.

Kataki R, Konwer D. Fuelwood characteristics of some indigenous woody species of north-east India. Biomass Bioenergy. 2001;20(1):17-23. http:// dx.doi.org/10.1016/S0961-9534(00)00060-X.

Kjällstrand J, Olsson M. Chimney emissions from small-scale burning of pellets and fuelwood examples referring to different combustion appliances. Biomass Bioenergy. 2002;27(6):557-61. http://dx.doi.org/10.1016/j.biombioe.2003.08.014.

Komilis D, Evangelou A, Giannakis G, Lymperis C. Revisiting the elemental composition and the calorific value of the organic fraction of municipal solid wastes. Waste Manag. 2012;32(3):372-81. http://dx.doi.org/ 10.1016/j.wasman.2011.10.034. PMid:22119517.

Krajnc N. Wood Fuels Handbook. 1st ed. Pristina: Food and Agriculture Organization of the United Nations; 2015.

Lemenih M, Bekele T. Effect of age on calorific value and some mechanical properties of three Eucalyptus species grown in Ethiopia. Biomass Bioenergy. 2004;27(3):223-32. http://dx.doi.org/ 10.1016/j.biombioe.2004.01.006.

Revista Árvore. 2017;41(5):e410507 


\section{Chemical and fuel properties of forestry...}

Mattos BD, Lourençon TV, Gatto DA, Serrano L, Labidi J. Chemical characterization of wood and extractives of fast-growing Schizolobium parahyba and Pinus taeda. Wood Mater Sci Eng. 2016;11(4):209-16. http://dx.doi.org/10.1080/ 17480272.2014 .970574$.

Miranda I, Gominho J, Mirra I, Pereira H. Chemical characterization of barks from Picea abies and Pinus sylvestris after fractioning into different particle sizes. Ind Crops Prod. 2012;36(1):395-400. http://dx.doi.org/10.1016/j.indcrop.2011.10.035.

Missio AL, Mattos BD, Gatto DA, Lima EA. Thermal analysis of charcoal from fast-growing eucalypt wood: Influence of raw material moisture content. J Wood Chem Technol. 2014;34(3):191-201. http://dx.doi.org/10.1080/02773813.2013.852588.

Olanders B, Steenari BM. Characterization of ashes from wood and straw. Biomass Bioenergy. 1995;8(2):105-15. http://dx.doi.org/10.1016/09619534(95)00004-Q.

Pirraglia A, Gonzalez R, Saloni D, Wright J, Denig J. Fuel properties and suitability of Eucalyptus benthamii and Eucalyptus macarthurii for torrefied wood and pellets. BioResources. 2012;7(1):217-35.

Santos PSB, Cademartori PHG, Prado R, Gatto DA, Labidi J. Composition and structure of organosolv lignins from four eucalypt species. Wood Sci Technol. 2014;48(4):873-85. http://dx.doi.org/ 10.1007/s00226-014-0646-Z.

Shanavas A, Kumar BM. Fuelwood characteristics of tree species in home gardens of Kerala, India. Agrofor Syst. 2003;58(1):11-24. http://dx.doi.org/ 10.1023/A:1025450407545.

Silvério FO, Barbosa LCA, Fidêncio PH, Cruz MP, Maltha CRA, Piló-Veloso D. Evaluation of chemical composition of Eucalyptus wood extracts after different storage times using principal component analysis. J Wood Chem Technol. 2011;31(1):26-41. http://dx.doi.org/10.1080/02773811003650463.

Technical Association of the Pulp and Paper Industry. T-204 om-97: Solvent extractives of wood and pulp 2000-2001. Atlanta: TAPPI Test Methods; 1997.

Technical Association of the Pulp and Paper Industry. T-222 om-98: Acid-insoluble lignin in wood and pulp 2000-2001. Atlanta: TAPPI Test Methods; 1998.

Technical Association of the Pulp and Paper Industry. T-257 cm-02: Sampling and preparing wood for analysis. Atlanta: TAPPI Test Methods; 2002.

Turinawe H, Mugabi P, Tweheyo M. Density, calorific value and cleavage strength of selected hybrid eucalypts grown in Uganda. Maderas Cienc Tecnol. 2014;16(1):13-24.

Vale AT, Brasil MAM, Carvalho CM, Veiga RAA. Produção de energia do fuste de Eucalyptus grandis Hill Ex-Maiden e Acacia mangium Willd em diferentes níveis de adubação. Cerne. 2000;6(1):83-8.

Villanueva M, Proupín J, Rodríguez-Añón JA, Fraga-Grueiro L, Salgado J, Barros N. Energetic characterization of forest biomass by calorimetry and thermal analysis. J Therm Anal Calorim. 2011;104(1):61-7. http://dx.doi.org/10.1007/s10973010-1177-y.

Wise LE, Murphy M, D'Addieco AA. Chlorite holocellulose, its fractionation and bearing on summative wood analysis and studies on the hemicelluloses. Paper Trade Journal. 1946;122(2):35-43.

Yaman S. Pyrolysis of biomass to produce fuels and chemical feedstocks. Energy Convers Manage. 2004;45(5):651-71. http://dx.doi.org/ 10.1016/S0196-8904(03)00177-8. 